\title{
Observations on the effect of salinity and photon fluence rate on the induction of sporulation and rhizoid formation in the green alga Enteromorpha prolifera (Müller) J. Agardh (Chlorophyta, Ulvales)
}

\author{
Akinori DAN, ${ }^{1, *}$ Masanori HIRAOKA, ${ }^{2}$ Masao OHNO ${ }^{3}$ AND Alan T. CRITCHLEY ${ }^{4}$ \\ ${ }^{1}$ Fisheries Research Institute, Tokushima Agriculture, Forestry and Fisheries Technology Center, \\ Hiwasa, Tokushima 779-2304, ${ }^{2}$ Kochi Prefectural Deep Seawater Laboratory, Muroto, \\ Kochi 781-7101, ${ }^{3}$ Usa Marine Biological Institute, Kochi University, Tosa, Kochi 781-1164, \\ Japan and ${ }^{4}$ Degussa Texturant Systems, France SAS, Baupte F50 500, France
}

\begin{abstract}
Although most members of the genus Enteromorpha are important edible green algae, some species are also potentially economically valuable crops. Samples of E. prolifera were obtained from the Yoshino River estuary, Tokushima, Japan and cultured in laboratory conditions at $10^{\circ} \mathrm{C}$, a salinity of $20 \mathrm{psu}$, under white light with $12 \mathrm{~h}$ light: $12 \mathrm{~h}$ dark cycle and at a photon fluence rate (PFR) of $40 \mu \mathrm{mol} / \mathrm{m}^{2}$ pers for 30 days. In the present study, the effect of salinity and PFR on the induction of reproductive cells and rhizoid formation were investigated. Synchronous formation of swarmers by thalli was induced in excised disks of $1.2 \mathrm{~mm}$ diameter after $2-5$ days incubation. The optimum salinity for maturation of reproductive cells was between 5.0 and $52.0 \mathrm{psu}$, and between 13.2 and $45.3 \mathrm{psu}$ for swarmer release, although the lower limit for swarmer release was $5.0 \mathrm{psu}$. Maturation of reproductive cells and swarmer release required a PFR higher than $16 \mu \mathrm{mol} / \mathrm{m}^{2} \mathrm{per}$ s. The minimum PFR for swarmer release was $8 \mu \mathrm{mol} / \mathrm{m}^{2}$ per s. Many rhizoids were formed between 1.6 and $52.0 \mathrm{psu}$ and photon fluence rates between 8 and $320 \mu \mathrm{mol} / \mathrm{m}^{2}$ pers. Rhizoids were formed in a polarized manner.
\end{abstract}

KEY WORDS: Enteromorpha prolifera, induced reproduction, photon fluence rate, rhizoid production, salinity.

\section{INTRODUCTION}

The green alga Enteromorpha prolifera (Müller) J. Agardh is an important edible seaweed in Japan. The alga grows in estuaries and is therefore exposed to widely changing salinity and influenced by tidal movement. However, wild stocks of this species have recently decreased due to water pollution in the Yoshino River estuary, Japan., ${ }^{1,2}$ Cultivated materials are now responsible for almost all of the processed Enteromorpha in Japan. In the past, seedling production has been obtained by 'natural' seeding methods of setting culture nets within natural populations in early autumn and spring. Swarmers discharged from the thalli of the wild plants settle onto the nets, which are

\footnotetext{
*Corresponding author: Tel: 81-884-771-251.
}

Fax: 81-884-772-744. Email: dan_akinori_1@pref.tokushima.jp Received 28 September 2001. Accepted 30 April 2002. then transferred to the cultivation grounds in the Yoshino River estuary. Annual production of Enteromorpha in the Yoshino River has sometimes fluctuated due to the influence of rain (low salinity) and unusual changes in water temperature. ${ }^{3} \mathrm{~A}$ study of the factors triggering swarmer discharge in Enteromorpha thalli would therefore be of importance for artificial seeding for cultivation purposes.

It is known that vegetative cells from the apex of an Enteromorpha thallus can transform directly into zoosporangia or gametangia. In the field, discharge of swarmers in certain Enteromorpha taxa has been reported to follow a lunar periodicity. ${ }^{4-7}$ In addition to tidal stimuli, optimum conditions of temperature, photon fluence rate and salinity are required for swarmer release. ${ }^{4,7}$ In the laboratory, it has been reported that cutting the thallus of Ulva mutabilis into small fragments induced a high degree of synchronous formation of swarmers. ${ }^{8}$ 
This method of inducing swarmer formation in U. mutabilis has allowed the determination of optimum conditions of PFR, day length, temperature, $\mathrm{pH}$, osmolarity and enrichment of seawater with nitrate and phosphate. ${ }^{9}$ Dan etal. reported optimum conditions for temperature and size of excised disks from E. prolifera thalli to promote reproductive maturation and swarmer release using the method of Nordby.,10 There have been some previous reports of optimum culture conditions for the sporulation in Ulva spp., ${ }^{8,11}$ and Enteromorpha spp. ${ }^{10}$ but there is little information on the lower limits of conditions that promote sporulation. Christie and Evans noted that no liberation from E. intestinalis thalli occurred at a salinity of less than $10 \mathrm{psu} .{ }^{4}$ Nordby reported that the lower limit of light intensity for sporulation was approximately $3-5 \mu \mathrm{mol} / \mathrm{m}^{2}$ per s in $U$. mutabilis. $^{9}$ Some observations on polarity in rhizoid production of Enteromorpha spp. have been reported. ${ }^{12-15}$ When the thallus of Enteromorpha is severed each of the cut cells, which are on the basal end of the thallus, forms a long attaching rhizoid. Furthermore, the relationship between rhizoid production and salinity in E. intestinalis has been reported. ${ }^{16}$ However, there are no reports on the effect of salinity and PFR on rhizoid formation in E. prolifera. In this paper, the optimum and lower limits of salinity and PFR for swarmer formation, release and rhizoid formation in excised disks of E. prolifera were investigated.

\section{MATERIALS AND METHODS}

\section{Algal material}

Thalli of E. prolifera were obtained from $5 \mathrm{~km}$ above the estuary of the Yoshino River, Tokushima $\left(34^{\circ} 03^{\prime} \mathrm{N}, 134^{\circ} 32^{\prime} \mathrm{E}\right)$, southern Japan in November 1999. These thalli were kept in beakers with $1 \mathrm{~L}$ of PES medium (salinity $20 \mathrm{psu}){ }^{17}$ Thalli were maintained for the sporulation experiment at $10^{\circ} \mathrm{C}$ with a $12 \mathrm{~h}$ light: $12 \mathrm{~h}$ dark (12L: 12D) cycle under white light at a photon fluence rate of $40 \mu \mathrm{mol} / \mathrm{m}^{2}$ per s for 30 days.

\section{Excised small disks and culture condition}

To investigate the optimum conditions of salinity for inducing the formation of reproductive cells, various concentrations of seawater were prepared by heating natural seawater $(32.1 \mathrm{psu})$ at $60^{\circ} \mathrm{C}$ or diluting sterile seawater with distilled water. A series of dilutions and concentrations of seawater were prepared: $0,5,10,15,20,40,60,80,100,120$,
$140,160,180,200 \%$ which were measured by salinometer (T. S. Digital lab; Turumi Seiki, Tokyo, Japan) to be: $0,1.6,3.3,5.0,6.6,13.2,19.9,26.3$, $32.1,39.4,45.3,52.0,59.4,66.3$ psu, respectively.

To determine the degree of swarmer formation and discharge, disks of $1.2 \mathrm{~mm}$ diameter were excised from the vegetative thallus $(150 \mathrm{~cm}$ length and $3-4 \mathrm{~mm}$ width) using a leather craft punch. A total of 336 disks were used. The disks were rinsed with diluted sterile seawater ( $3.3 \mathrm{psu}$ ) and transferred to tissue culture microplates $(48 \times 0.6 \mathrm{~mL}$ wells; Iwaki, Tokyo, Japan). The disks were moved, one by one, into individual wells filled with seawater of different salinities. The disks were incubated at $20^{\circ} \mathrm{C}$ under white light of $40 \mu \mathrm{mol} / \mathrm{m}^{2}$ per s PFR with a $12 \mathrm{~L}: 12 \mathrm{D}$ regimen for 5 days. Daily microscopic observations were made during 9:00 and 10:00 AM. The mature area of the thallus, which was to form swarmers, was recognized by its yellow/ brown color. Disks, having a mature area wider than $50 \%$ were designated to be 'reproductively mature'. Released swarmers can easily be recognized by empty white cells. Disks with swarmers discharged over an area $>50 \%$, were defined as 'swarmer release'. The proportion of reproductive maturation and swarmer release was determined in each group. The number of disks with regenerated rhizoids was counted 3 days after excision.

To study the effect of PFR, 240 disks of $1.2 \mathrm{~mm}$ in diameter were excised from fresh thallus material $(120 \mathrm{~cm}$ length and $4 \mathrm{~mm}$ width). Disks were washed in sterile seawater (20 psu) and transferred to 48 well microplates. Each disk was transferred to a well with $0.6 \mathrm{~mL}$ of $20 \mathrm{psu}$ autoclaved seawater. These plates were then placed at $20^{\circ} \mathrm{C}$, under white light of PFR values: $0,4,8,16,24,40,80,160$, $320 \mu \mathrm{mol} / \mathrm{m}^{2}$ pers with a $12 \mathrm{~L}: 12 \mathrm{D}$ regimen for 5 days. The light source was provided by ceiling lights in two sets of $40 \mathrm{~W}$ white fluorescent lamps (Hitachi, Tokyo, Japan) and four $27 \mathrm{~W}$ white fluorescent lamps (Mitubishi, Tokyo, Japan). Different PFR values were established by positioning the plates at different distances from the light source and by using layers of black mesh cloth as light filters. Photon fluence rates were measured with a light meter (LI-250; Li-cor, Lincoln, NB, USA) with a quantum sensor LI-190SA. Observations were made of reproductive maturation, swarmer release and rhizoid formation.

\section{Rhizoid production}

To ascertain whether rhizoids formed only at the edge of the disk, which had been proximal to the base of the thallus, 25 disks of $4.2 \mathrm{~mm}$ diameter were excised from the thallus of E. prolifera $(140 \mathrm{~cm}$ 

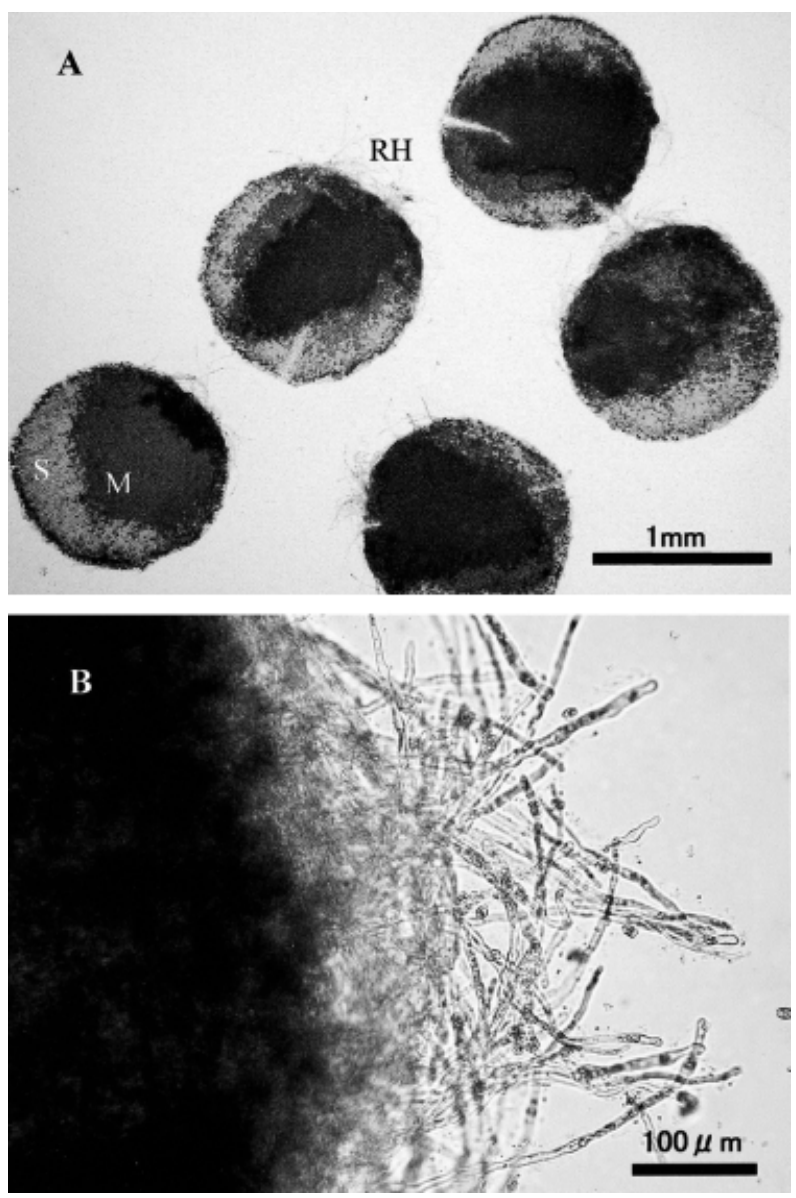

Fig. 1 Disks incubated in $45.3 \mathrm{psu}$ autoclaved seawater for 5 days at $20^{\circ} \mathrm{C}$ with a light (L)/dark (D) cycle of $12 \mathrm{~h} \mathrm{~L}: 12 \mathrm{~h} \mathrm{D}$ and fluence rate of $40 \mu \mathrm{mol} / \mathrm{m}^{2}$ pers. (a) Lighter areas of the disks indicate the region of mature reproductive cells $(\mathrm{M})$ and swarmer release (S). $\mathrm{RH}$ indicates rhizoid production. (b) Rhizoid development from the edge of the disk magnified from the area $\mathrm{RH}$ indicated in (a).

length and 3-8 $\mathrm{mm}$ width), and the distal edge was marked with a small hole of $1.2 \mathrm{~mm}$ diameter. Perforations were made in the disks in order to examine the polarity of rhizoidal production. These were incubated in 20 psu autoclaved seawater for 5 days at $20^{\circ} \mathrm{C}$ with a $12 \mathrm{~L}: 12 \mathrm{D}$ cycle and $40 \mu \mathrm{mol} / \mathrm{m}^{2}$ per s PFR.

\section{RESULTS}

\section{Sporulation and salinity}

Some disks, which had sporulated and produced rhizoids, are shown in Fig. 1. Polarity was noted in rhizoid production. Rhizoids formed only at the opposite edge of the disk to that which released

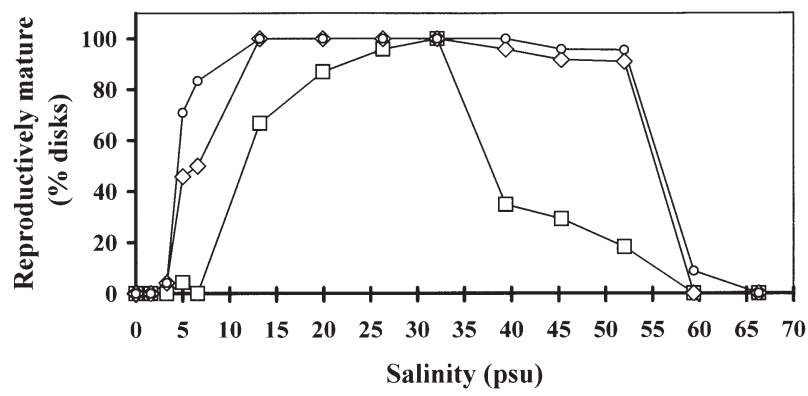

Fig. 2 'Reproductively mature' versus salinity. Disks were excised from thallus and cultured for $(\square) 3$ days; $(\diamond)$ 4 days; and (○) 5 days. Proportion (\%) of disks having more than $50 \%$ of mature reproductive cells are plotted versus salinity.

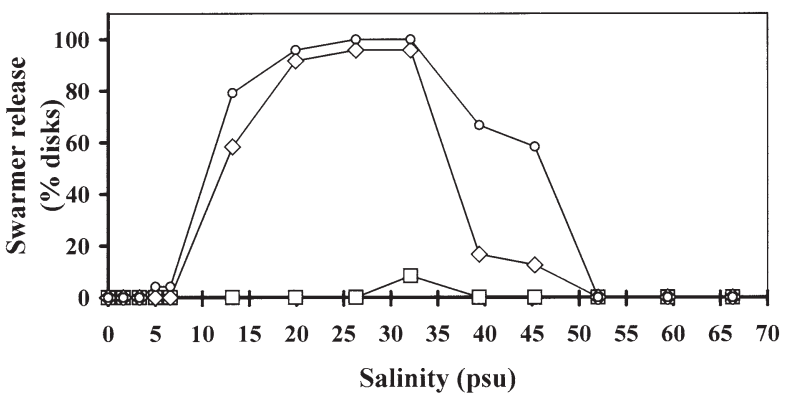

Fig. 3 'Swarmer release' versus salinity. Disks were cultured for $(\square) 3$ days; $(\diamond) 4$ days; and $(\bigcirc) 5$ days. Proportion (\%) of disks having more than $50 \%$ of cells released as swarmers are plotted versus salinity.

swarmers. The relative frequency (\%) of reproductively mature disks at different salinities is shown in Fig. 2. After 5 days, a relative frequency of $>70 \%$ reproductively mature disks was observed in the salinity range $5.0-52.0 \mathrm{psu}$. Production declined when salinity was $<6.6$ psu and $>59.4$ psu No reproductively mature disks were found at salinities of 0 , 1.6 and $66.3 \mathrm{psu}$

The relative frequency (\%) of swarmer release in disks at a range of salinities is shown in Fig. 3. After 4 and 5 days a relative frequency of $>50 \%$ swarmer release was recorded in the $13.2-45.3$ psu, salinity range. The occurrence of swarmer release declined at salinity levels $<13.2$ and $>45.3$ psu. No swarmer release was observed at $<3.3$ and $>59.4$ psu.

\section{Sporulation and photon fluence rate}

The relative frequency (\%) of reproductively mature disks at various PFR values is shown in Fig. 4. After 5 days culture, relative frequencies of $100 \%$ reproductively mature disks were found at PFR values $>16 \mu \mathrm{mol} / \mathrm{m}^{2}$ pers. No reproductively 


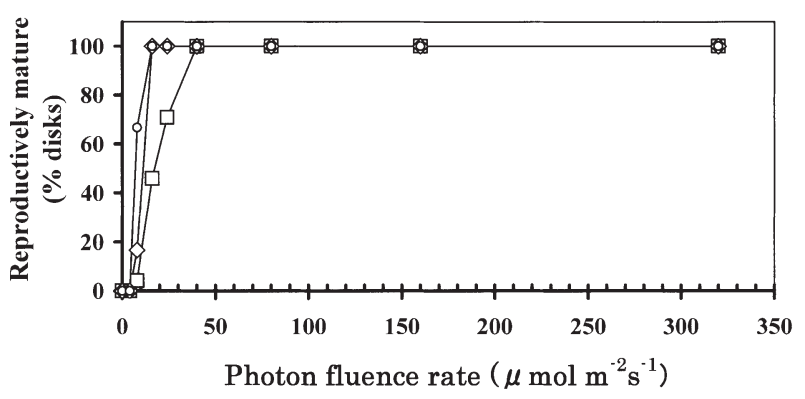

Fig. 4 'Reproductively mature' versus photon fluence rate. Disks were cultured for $(\square) 3$ days; $(\diamond) 4$ days; and (○) 5 days. Proportion (\%) of disks having more than $50 \%$ mature reproductive cells are plotted versus photon fluence rate.

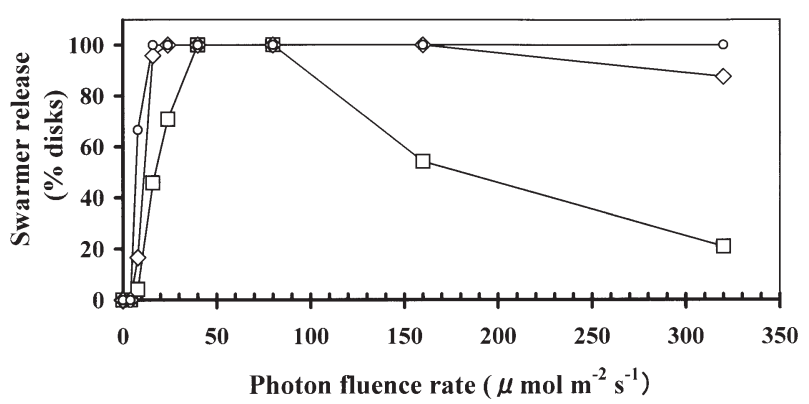

Fig. 5 'Swarmer release' versus photon fluence rate. Disks were cultured for $(\square) 3$ days; $(\diamond) 4$ days; and $(\bigcirc) 5$ days. Proportion (\%) of disks having more than $50 \%$ of cells released as swarmers are plotted versus photon fluence rate.

mature disks occurred at PFR values $<4 \mu \mathrm{mol} / \mathrm{m}^{2}$ pers. The relative frequency of reproductively mature disks reached $100 \%$ after 3 days in cultures $>40 \mu \mathrm{mol} / \mathrm{m}^{2}$ pers PFR. An increase in photon fluence rate also increased the relative frequency of reproductively mature disks after the tissue disks were excised.

The relative frequency (\%) of swarmer release in disks under various PFR values is shown in Fig. 5. After 5 days, $100 \%$ swarmer release was observed at $>16 \mu \mathrm{mol} / \mathrm{m}^{2}$ pers PFR. No swarmer release occurred when PFR was $<4 \mu \mathrm{mol} / \mathrm{m}^{2}$ per s.

\section{Rhizoid production}

The relative frequency (\%) of excised disks producing rhizoids at various salinities after 3 days is shown in Fig. 6. No rhizoids were found at salinities of 0, 59.4 and 66.3 psu. Relative frequencies of $>70 \%$ of disks with rhizoids were found within the salinity range of $1.6-52.0 \mathrm{psu}$.

Figure 7 shows the relative frequency (\%) of disks with rhizoids under various PFR values after

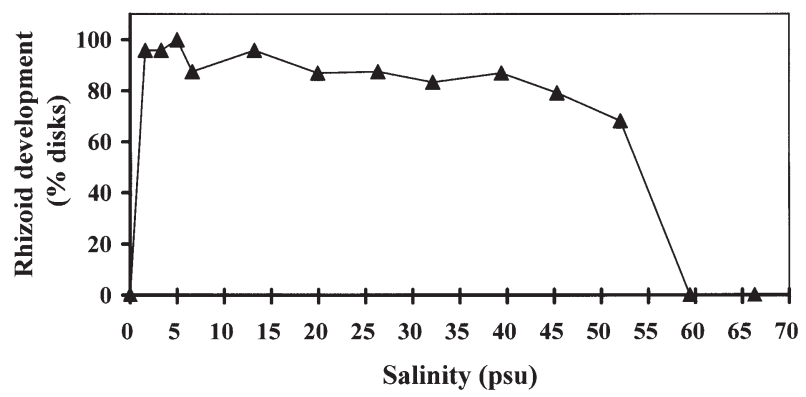

Fig. 6 Relationship between rhizoid development and salinity. Proportion (\%) of disks having regenerated rhizoids are plotted versus salinity. Disks were cultured for 3 days.

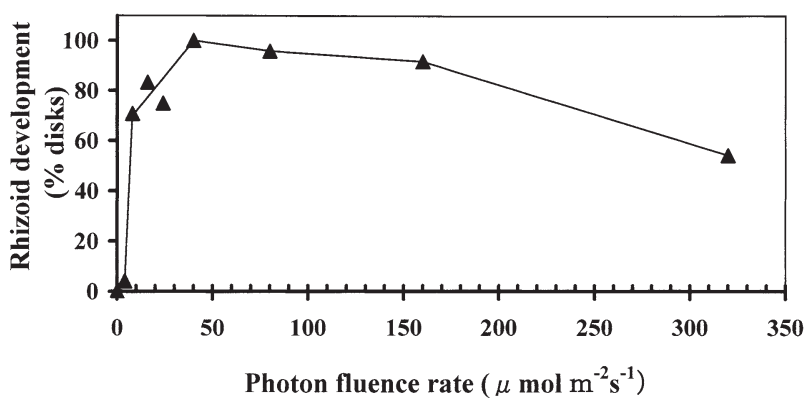

Fig. 7 Relationship between rhizoid development and photon fluence rate. Proportion (\%) of disks having regenerated rhizoids are plotted versus photon fluence rate. Disks were cultured for 3 days.

3 days. No rhizoids were found at $0 \mu \mathrm{mol} / \mathrm{m}^{2}$ per s conditions. As PFR increased, the relative frequency of disks with rhizoids also increased between 4 and $40 \mu \mathrm{mol} / \mathrm{m}^{2}$ pers, but a decrease was observed at PFR values $>80 \mu \mathrm{mol} / \mathrm{m}^{2}$ per s.

Figure 8 shows an excised disk with a small circular hole after 5 days in culture. Rhizoids formed at both the cut edge of the disk and the small hole, which indicated the original position, proximal to the base of the thallus. Many rhizoids appeared only on the cut surfaces, which had been originally proximal to the base of the thallus, indicating some degree of polarity in rhizoid initiation (Figs 8b,c).

\section{DISCUSSION}

Dan etal. demonstrated a reliable method for the production of reproductive cells from vegetative cells within a few days in E. prolifera by cutting thalli into small fragments. ${ }^{18}$ Nordby proposed that the vegetative thalli of $U$. mutabilis produced some substances that inhibited swarmer formation and that leaked out when a thallus was fragmented and allowed swarmer formation to occur. ${ }^{9,10}$ Stratmann 

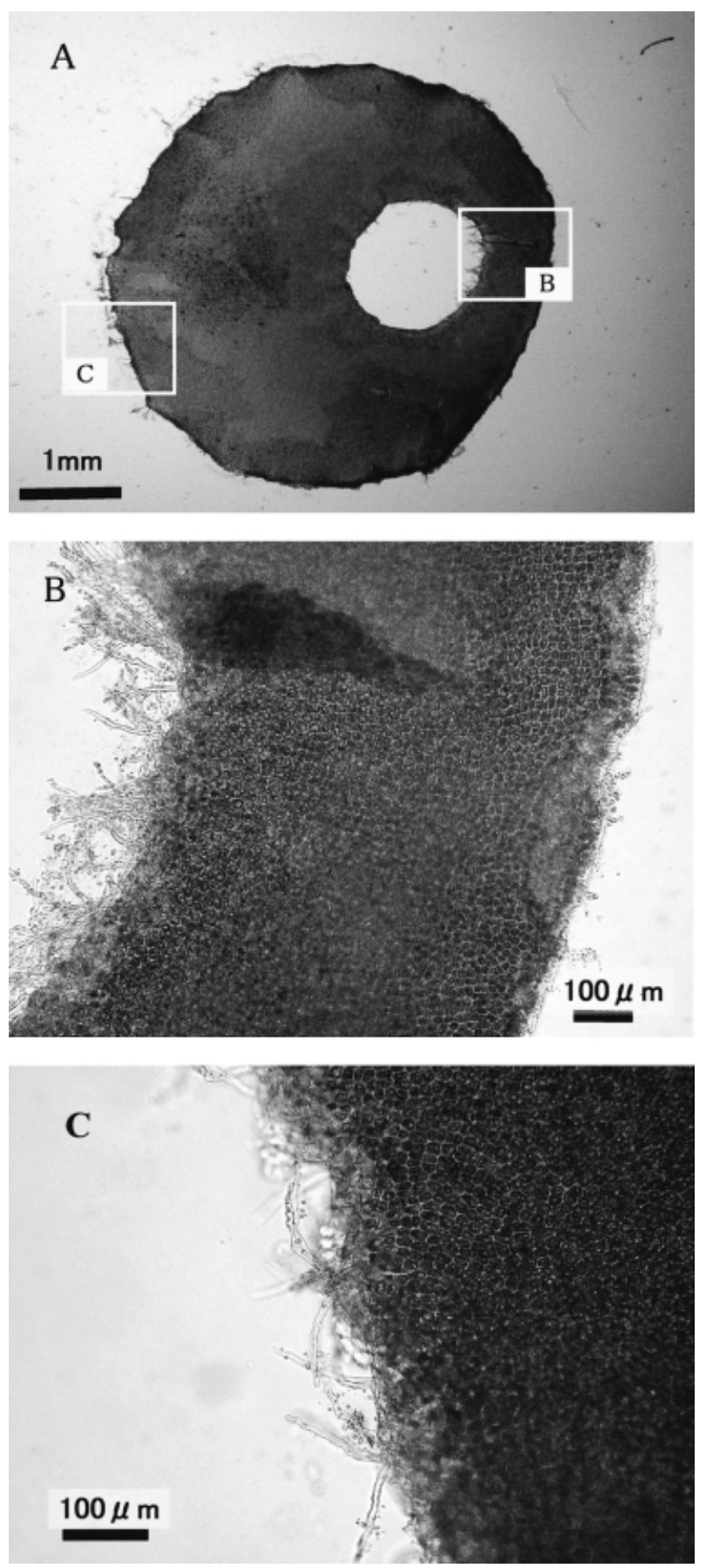

Fig. 8 Rhizoid development from an excised disk. (a) A circular hole of $1.2 \mathrm{~mm}$ in diameter was punched out of a disk of $4.2 \mathrm{~mm}$ in diameter. The disk was cultured at $20^{\circ} \mathrm{C}$ for 5 days with a photon fluence rate of $40 \mu \mathrm{mol} / \mathrm{m}^{2}$ per s with a light (L)/dark (D) cycle of 12L: 12D. (b) Rhizoids regenerated from the distal part of the tissue towards the hole, magnified from the area B indicated in (a). (c) Rhizoids formed from the proximal edge of the disk. Magnified from the area $\mathrm{C}$ indicated in (a). et al. recently reported that the thallus of $U$. mutabilis produced at least two types of sporulation inhibitor, one of which was a glycoprotein and the other a non-protein of very low molecular mass. ${ }^{19}$ Dan etal. reported that the optimum culture conditions for reproductive maturation and increased swarmer release of E. prolifera were promoted by a small disk size of $0.9 \mathrm{~mm}$ diameter and a temperature of $20-25^{\circ} \mathrm{C}$. Larger disk size decreased the degree of reproductive maturation..$^{10}$ These results also suggested the presence of reproductive maturation inhibitors in vegetative thalli of $E$. prolifera. The relationship between salinity and sporulation in this study indicated suitable conditions for reproductive maturation in the range 5.0-52.0 psu. However, suitable conditions for swarmer release were in the narrower salinity range of 13.2$45.3 \mathrm{psu}$. Nordby reported a higher percentage sporulation in fragments of $U$. mutabilis after 4 days in a salinity range of $13-45 \mathrm{psu} .^{9}$ The results for the salinity range in this study were not greatly different from those of Nordby. The appropriate salinity range for growth in E. intestinalis germlings was $16-40 \mathrm{psu}^{20}$ The optimum salinity range for the growth in E. prolifera germlings was 15.7$35.0 \mathrm{psu}^{21}$ Being an euryhaline seaweed, E. prolifera can grow in a range of salinity from 0.3 to $33.1 \mathrm{psu}$ in the Shimanto River, southern Japan. ${ }^{22}$ In the present study, we showed that the appropriate salinity for swarmer release of $E$. prolifera occurred in the range $13.2-45.3 \mathrm{psu}$; this value seems to be quite narrow, considering the fluctuating salinity of the alga's habitat.

Since the phase of swarmer release followed that of reproductive maturation under suitable conditions, previous investigators did not distinguish between the two phases. However, in extreme conditions the phase of reproductive maturation is not completed by the discharge of swarmers. A distinction must be made between the two phases. When the concentration of seawater was at the extreme of the ranges (i.e. 3.3 and 59.4 psu) the disks were observed to contain reproductively mature cells, but no swarmer discharge occurred. Therefore, the process of swarmer release required a salinity of $>5.0 \mathrm{psu}$.

The commercial cultivation of Enteromorpha is carried out in the Yoshino River estuary, Tokushima, southern Japan where the salinity within the cultivation grounds is usually within the range of 20-30 psu and is therefore suitable for swarmer release. The results of the present study showed that swarmer release did not occur at extremely low salinities (i.e. $<6.6 \mathrm{psu}$ ). Reduced salinity, at the cultivation grounds, due to heavy rainfall is known to cause a decline in growth also and cause the disappearance of thalli. ${ }^{2}$ There was a 
lag period between low salinity due to heavy rain and the loss of thalli. In the reduced salinity range of 3.3-6.6 psu, the Enteromorpha thalli were able to persist and swarmers even developed within the zoosporangia or gametangia. However, swarmers were not released at these low salinities. Once the salinity within the cultivation grounds increases to $>13.2 \mathrm{psu}$, swarmer discharge begins and some of the mature thalli are lost in the process. Therefore there can be some time between the point of swarmer production and their final release depending upon the salinity conditions that the Enteromorpha plants are exposed to.

In the present study, the optimal PFR for reproductive maturation and swarmer release was $>16 \mu \mathrm{mol} / \mathrm{m}^{2}$ pers. Furthermore, an increase in PFR tended to promote the onset of reproductive maturation in the disks. After 5 days, the relative frequency of reproductively mature disks was $100 \%$ at all PFR values $>16 \mu \mathrm{mol} / \mathrm{m}^{2}$ per s. Nordby reported that an optimum PFR for reproductive maturation in fragments of $U$. mutabilis (2 days after preparation) was $>42 \mu \mathrm{mol} / \mathrm{m}^{2}$ pers and the lower limit of PFR, which evoked any reproductive maturation response, appeared to be around 3$5 \mu \mathrm{mol} / \mathrm{m}^{2}$ per s. ${ }^{9}$ In the present study, the lower limit of PFR for reproductive maturation was $8 \mu \mathrm{mol} / \mathrm{m}^{2}$ pers. Therefore, the observations reported from this study were not greatly different from those of Nordby. However, the optimum PFR value for reproductive maturation is lower than that of Nordby. This may be due to the difference between the species used. However, because the observation period of Nordby was only 2 days, there is a possibility that reproductive maturation was advanced at PFR values lower than $42 \mu \mathrm{mol} / \mathrm{m}^{2}$ pers.

The artificial seeding technique for Enteromorpha cultivation is to place culture nets and cut fragments of thallus into tanks to allow the released swarmers to attach to the culture nets. ${ }^{18}$ When a large number of nets are placed into the tanks, the PFR in the central part of nets (compared to the outside) declines significantly. If optimum swarmer release is obtained at low PFR values of $16 \mu \mathrm{mol} / \mathrm{m}^{2}$ pers, then artificial seeding is promoted by using a large number of nets per tank. It is considered that artificial seeding is enhanced by swarmer release under low photon fluence rates.

Lersten and Voth reported that reproductive sections of thallus from E. clathrata, E. intestinalis, and E. linza that did not discharge their contents completely went on to form rhizoids. ${ }^{13}$ Dan etal. reported that disks excised from E. prolifera also produced rhizoids. ${ }^{10}$ Lersten and Voth also demonstrated polarity in that rhizoids formed only at the end of tissue that had been proximal to the base of the whole plants of E. intestinalis and E. linza. ${ }^{13}$ The present study, clearly showed that disks excised from E. prolifera formed rhizoids and that their rhizoidal formation was also influenced by polarity as in E. intestinalis and E. linza. Rhizoids were not only produced at the edge of the excised disk (in a basal direction) but also formed at the upper part of the tissue cut out of a small hole in the disk. Therefore, differentiation of rhizoids was determined by the position and orientation of the disk on the mature thallus (i.e. they are formed relative to the position proximal to the base of the plant).

When a thallus of Enteromorpha is cut into pieces, rhizoids are often formed by each of the resulting fragments. ${ }^{10,12-15}$ It is known that reproductive maturation and swarmer release occur in the upper region of the fragments (away from the original base of the whole thallus) ${ }^{12,14}$ It was observed that when reproductive maturation does not occur or only occurs partially, then fragments increased in size. ${ }^{10}$ It is considered that rhizoid production and reproductive maturation of thallus fragments occur independently of one other. When the thallus is cut into very small fragments, reproductive maturation and swarmer release advance rapidly, and rhizoids are not always formed. ${ }^{10,13}$ Very rapid reproductive maturation and release of swarmers does not allow an opportunity for rhizoids to differentiate, all of the vegetative cells become reproductive and therefore rhizoids are unable to differentiate.

The experiment used to induce reproductive maturity in $U$. pertusa showed a greater effect on sporophytes than on gametophytes. ${ }^{11}$ The life history of E. prolifera may be like that of U. pertusa in that there is an alternation of isomorphic generations. In the present study, it was difficult to distinguish between the two phases because the natural thalli of E. prolifera were used. Therefore, further studies are required to investigate whether our Enteromorpha samples are sporophytes or gametophytes.

Little information is available on rhizoid formation in 5-6 mm segments of E. intestinalis cultured within the salinity range of $0-102 \mathrm{psu}$. Reed and Russell demonstrated rhizoid production, recorded as percentage regeneration and responses to salinity for E. intestinalis, collected from the eulittoral zone, littoral fringe and maritime populations. ${ }^{16}$ In their report, none of the segments from the eulittoral zone populations formed rhizoids at salinities of 0 or $95 \mathrm{psu}$. The degree of rhizoid formation declined markedly at 64 psu. In this paper, no rhizoids were produced at salinities of $0,59.4$ or $66.3 \mathrm{psu}$. These results are quite similar to those of Reed and Russell. The results in the present study, for the range of suitable salinities 
and PFR for rhizoid production, provide useful information for the production of seedlings of Enteromorpha using tissue cultured fragments. If large fragments of cut thalli can be placed within the culture nets it would be possible to grow the crop earlier than using the normal methods of natural seeding. Cutting the thalli of Enteromorpha promotes the regeneration of new branches and therefore efficiently seeds the nets for commercial Enteromorpha culture. ${ }^{14}$

\section{ACKNOWLEDGMENTS}

This study was supported in part by the New Energy and Industrial Technology Development Organization (NEDO).

\section{REFERENCES}

1. Ohno M, Miyanoue K. The ecology of the food alga Enteromorpha prolifera. Rep. Usa Mar. Biol. Inst. Kochi Univ. 1980; 2: 11-17.

2. Ohno M, Matuoka M. Aonori (Enteromorpha prolifera). In: Miura A (ed.) Cultivation of Edible Algae in Japan. Kouseisha Kouseikaku, Tokyo. 1992, 61-68.

3. Ohno M. Cultivation of the green algae, Monostroma and Enteromorpha 'Aonori'. In: Ohno M, Critchley AT (eds). Seaweed Cultivation and Marine Ranching. JICA, Yokosuka. 1993, 7-15.

4. Christie AO, Evans LV. Periodicity in the liberation of gametes and zoospores of Enteromorpha intestinalis Link. Nature 1962; 193: 193-194.

5 Ohno M, Mairh OP, Chauhan VD, Tewari A, Oza RM, Joshi HV, Pandy RS, Rao PS. Mass cultivation of green alga Enteromorpha on the coast of Okha, India. Rep. Usa Mar. Biol. Inst. Kochi Univ. 1981; 3: 51-59.

6 Pandy RS, Ohno M. An ecological study of cultivated Enteromorpha. Rep. Usa Mar. Biol. Inst. Kochi Univ. 1985; 7: 21-31.

7. Pringle JD. Swarmer release and distribution of life-cycle phases of Enteromorpha intestinalis (L.) (Chlorophyta) in relation to environmental factors. J. Exp. Mar. Biol. Ecol. 1986; 100: 97-111.

8. Nordby $\emptyset$, Hoxmark RC. Changes in cellular parameters during synchronous meiosis in Ulva mutabilis $\mathrm{F} ø$ yn. Exp. Cell Res. 1972; 75: 321-328.

9. Nordby $\emptyset$. Optimal conditions for meiotic spore formation in Ulva mutabilis F ø yn. Bot. Mar. 1977; 20: 19-28.

10. Dan A, Hiraoka M, Ohno M. On the induction of reproductive cell formation in the green alga, Enteromorpha prolifera: Relationship of temperature and size of tissue disk. Suisanzoshoku 1998; 46: 503-508.

11. Hiraoka M, Enomoto S. The induction of reproductive cell formation of Ulva pertusa Kjellman (Ulvales, Ulvophyceae). Phycol. Res. 1998; 46: 199-203.

12. Eaton JW, Brown JG, Round FE. Some observations on polarity and regeneration in Enteromorpha. Br. Phycol. Bull. 1966; 3: 53-62.

13. Lersten NR, Voth PD. Experimental control of zooid discharge and rhizoid formation in the green alga Enteromorpha. Bot. Gaz. 1960; 122: 33-45.

14. Moss B, Marsland A. Regeneration of Enteromorpha. Br. Phycol. J. 1976; 11: 309-313.

15. Lee TF, Wichroski M. Polar regeneration in Enteromorpha prolifera. J. Phycol. 1996; 32: 27.

16. Reed RH, Russell G. Adaptation to salinity stress in populations of Enteromorpha intestinalis (L.) Link. Estuarine Coastal Mar. Sci. 1979; 8: 251-258.

17. Provasoli L. Media and prospects for the cultivation of marine algae. In: Watanabe A, Hattori A (eds). Culture and Collections of Algae. Proceedings of the U.S.-Japan Conference, Hakone, September 1966. Japanese Society of Plant Physiology, Hakone. 1968; 63-75.

18. Dan A, Ohno M, Matuoka M. Cultivation of the green alga Enteromorpha prolifera using chopped tissue for artificial seeding. Suisanzoshoku 1997; 45: 5-8.

19. Stratmann J, Paputsoglu G, Oertel W. Differentiation of Ulva mutabilis (Chlorophyta) gametangia and gamete release are controlled by extra-cellular inhibitors. J. Phycol. 1996; 32: 1009-1021.

20. Kim KY, Lee IK. The germling of Enteromorpha intestinalis (Chlorophyta) in laboratory culture under different combinations of irradiance and salinity and temperature and salinity. Phycologia 1996; 35: 327-331.

21. Htun US, Ohno M, Mizuta S. Effect of salinity and temperature on the growth of green alga, Enteromorpha prolifera, in culture. Rep. Usa Mar. Biol. Inst. Kochi Univ. 1986; 8: 9-13.

22. Ohno M, Takahashi I. The horizontal and vertical distribution of the food alga Enteromorpha prolifera in Shimanto River, southern Japan. Rep. Usa Mar. Biol. Inst. Kochi Univ. 1988; 10: 45-54. 